Jurnal Mahasiswa BK An-Nur : Berbeda, Bermakna, Mulia

Volume 7 Nomor 1 Tahun 2021

Tersedia Online: https://ojs.uniska-bjm.ac.id/index.php/AN-NUR

p-ISSN. 2460-9722 | e-ISSN. 2622-8297

\title{
PERAN KELUARGA DALAM PENGELOLAAN EMOSI ANAK USIA GOLDEN AGE DI DESA GAMBARSARI
}

\author{
Iqoh Maulina $^{1}$ dan Alief Budiyono ${ }^{2}$ \\ ${ }^{1}$ IAIN Purwokerto, Mahasiswa Fakultas Dakwah, Program Studi Bimbingan dan Konseling Islam \\ ${ }^{2}$ IAIN Purwokerto, Dosen Fakultas Dakwah \\ 1717101063@mhs.iainpurwokerto.co.id dan alief@iainpurwokerto.ac.id
}

\begin{abstract}
ABSTRAK
Keluarga merupakan lingkup utama yang mengajarkan anak berbagai emosi yang dapat diungkapkan ketika anak mengalami suatu peristiwa. Dalam usia golden age ini, anak dapat berkembang pesat dalam memperoleh informasi dan anak cenderung meniru hal-hal yang dilakukan oleh orang tua anak. Orang tua sangat berperan penting dalam perkembangan emosional anak, agar supaya anak dapat terus berinteraksi dan berkomunikasi dengan lingkungan sekitar sesuai dengan peristiwa yang terjadi dan anak dapat mengaplikasikan emosinya secara tepat. Dengan menggunakan metode deskriptif kualitatif dan menggunakan teori Social learning theory merupakan teori yang menjelaskan sosialisasi dan pengaruhnya terhadap perkembangan kepribadian anak. Dengan menggunakan teori tersebut dapat disimpulkan bahwa peran orang tua sangat berpengaruh terhadap sosialisasi anak dan perkembangan kepribadian anak terutama dalam mengelola emosi anak, yang mana anak akan cenderung menirukan terlebih dahulu apa yang dia lihat dari sekeliling dia terutama dari orang tua dan keluarga terdekatnya.
\end{abstract}

Kata Kunci: Konseling Keluarga, Emosi, Golden age

\begin{abstract}
Family is the main scope that teaches children various emotions that can be expressed when children experience an event. In this golden age, children can develop rapidly in obtaining information and children tend to imitate things that are done by the child's parents. Parents play an important role in the emotional development of children, so that children can continue to interact and communicate with the surrounding environment in accordance with the events that occur and children can apply their emotions appropriately. By using qualitative descriptive methods and using social learning theory is a theory that explains socialization and its effects on children's personality development. By using this theory, it can be concluded that the role of parents is very influential on children's socialization and personal development, especially in managing children's emotions, in which children will tend to first imitate what they see from their surroundings, especially from their parents and their closest family.
\end{abstract}

Keywords: Family Counseling, Emotional, Golden age

Dipublikasikan Oleh :

UPT Publikasi dan Pengelolaan Jurnal

Universitas Islam Kalimantan Muhammad Arsyad Al-Banjari Banjarmasin 


\section{Iqoh Maulina $^{1}$ dan Alief Budiyono ${ }^{2}$ \\ Jurnal Mahasiswa BK An-Nur : Berbeda, Bermakna, Mulia \\ Volume 7 Nomor 1 Tahun 2021 \\ Tersedia Online: https://ojs.uniska-bjm.ac.id/index.php/AN-NUR \\ p-ISSN. 2460-9722 | e-ISSN. 2622-8297}

\section{PENDAHULUAN}

Keluarga (Yulis Jamiah, Jurnal Matematika, PMIPA, FKIP, 2012:2) merupakan lingkungan sosial pertama yang berpengaruh besar terhadap pertumbuhan dan perkembangan anak. Fungsi dari keluarga ialah membangun komunikasi yang melibatkan mental, sosial, emosional dan mengatasi berbagai masalah yang dialami oleh anak. Penanaman kebiasaan yang keliru dari masa anak-anak hingga dewasa dapat berpengaruh buruk dalam membentuk karakter dan kepribadian anak. Bukan hal mudah untuk membentuk karakter dan kepribadian anak yang ideal, dibutuhkan pendekatan komprehensif yang dilakukan secara eksplisit, sistematis dan berkesinambungan yang dimulai sejak kecil dalam lingkungan keluarga. Dalam pengasuhan anak, orang tua sangat berperan penting dalam berbagai hal seperti pendidikan anak pertama, akhlak, moral, emosi dan lain sebagainya yang akan ditiru oleh anak. Sejak usia dini anak-anak akan lebih banyak meniru sikap dan tingkah laku orang tuanya atau anggota keluarganya. Bagaimana seorang anak dapat memperhatikan dan merangsang apa yang dia lihat yang kemudian akan memicu anak memperlihatkan emosi apa yang dia perlihatkan.

Fase perkembangan dapat dikelompokkan menjadi perkembangan biologis, psikologis dan didaktis (Ahmad Yusuf Prasetiawan, Jurnal Pendidikan dan Pembelajaran Dasar, 6, 1, Juni 2019: 100-101). Perkembangan biologis berfungsi sebagai daya pikir seseorang secara neurosis. Perkembangan psikologis merupakan perilaku dan kepribadian untuk menuju kemandirian yaitu mampu berelasi terhadap realitas yang ada. Sedangkan perkembangan didaktis yang meliputi aspek afeksi, kognisi dan psikomotori. Dalam kepribadian tersebut terdapat bentuk kesadaran, ingatan, pikiran yang selamanya dapat beriringan terus dengan stimulus. Golden age terjadi hanya satu kali sehingga sangat penting untuk merangsang pertumbuhan otak anak yang dimulai dari pemberian perhatian, kesehatan anak, pendidikan anak dan penyediaan makanan yang bergizi yang dapat menunjang pertumbuhan dan perkembangan anak baik dari fisik dan psikis.

Golden age merupakan bagian dari perkembangan psikologis manusia. Dikatakan golden age karena pada usia ini kemampuan otak anak untuk berpikir dan menyerap informasi sangat tinggi, informasi apapun yang diberikan akan berpengaruh pada anak-anak di masa yang berikutnya. Terdapat beberapa pakar yang menyebutkan perbedaan rentang waktu golden age yaitu 0-2 tahun, 0-3 tahun, 0-5 tahun atau 0-8 tahun. Awal masa kehidupan manusia merupakan masa emas (golden age) yang disebut sebagai masa penting dan tak akan terulang kembali. Dimasa inilah peran keluarga, lingkungan, pendidikan dituntut untuk mampu membentuk karakter anak secara benar dan tepat untuk menumu keberhasilan perkembangan yang sesungguhnya dalam mengembangkan berbagai potensi, skill, emosional maupun spiritual (Ahmad Yusuf Prasetiawan, Jurnal Pendidikan dan Pembelajaran Dasar, 6, 1, Juni 2019: 100-101).

Masa usia dini atau golden age merupakan masa emas pada seluruh aspek perkembangan manusia baik secara fisik, kognisi emosi ataupun sosial. Salah satu aspek penting bagi anak usia dini ialah terletak pada aspek emosi. Menurut pendapat Goleman, Izard dan Ackerman, Le Doux, emosi merupakan perasaan yang secara psikologis dan fisiologis dimiliki oleh anak dan dapat digunakan untuk merespons peristiwa yang ada disekitarnya. Emosi merupakan hal yang penting bagi anak usia dini karena dapat memusatkan perhatian dan emosi juga dapat memberikan sentuhan bagi anak untuk berpikir sesuai dengan kebutuhannya (Wisjnu Martani, Jurnal Psikologi, 39, 1, Juni 2012: 112). Emosi sangat membantu anak untuk dapat berkembang dan terus berkomunikasi dengan lingkungan sekitarnya. Emosi seseorang dapat berkembang dari waktu ke waktu dimulai dari yang sederhana ke yang lebih kompleks. Menurut Bronfenbreuner ada beberaps sistem yang berpengaruh terhadap perkembangan anak yaitu mikrosistem, ekosistem, mesosistem, makrosistem dan kronosistem. Salah satu dari sistem tersebut yang paling berpengaruh dalam perkembangan anak adalah mikrosistem. Lingkungan mikro menurut Bronfenbreuneur ialah situasi lingkungan yang menyebabkan anak dapat melakukan kontak langsung dan saling mempengaruhi. Lingkungan mikro ini sangat berperan khusus terhadap perkembangan anak, karena dalam mikrosistem ini ada unsur kualitas dan kuantitas pengasuhan orang tua (Wisjnu Martani, Jurnal Psikologi, 39, 1, Juni 2012: 113). Menurut Lickona berpendapat bahwa variasi dalam situasi akan menghasilkan variasi dalam perilaku. Membangun suasana dalam situasi mendekati kehidupan yang sebenarnya, dapat menyebabkan anak menjadi kaya pengalaman. Anak akan cenderung bertindak dan berpikir dari sisi kognitif maupun non kognitif.

Dipublikasikan Oleh :

UPT Publikasi dan Pengelolaan Jurnal

Universitas Islam Kalimantan Muhammad Arsyad Al-Banjari Banjarmasin 


\section{Iqoh Maulina $^{1}$ dan Alief Budiyono ${ }^{2}$ \\ Jurnal Mahasiswa BK An-Nur : Berbeda, Bermakna, Mulia \\ Volume 7 Nomor 1 Tahun 2021 \\ Tersedia Online: https://ojs.uniska-bjm.ac.id/index.php/AN-NUR \\ p-ISSN. 2460-9722 | e-ISSN. 2622-8297}

Dengan begitu mereka dapat berkembang secara optimal menjadi manusia seutuhnya.

Social learning theory (Qurrotul Ainiyah, Jurnal Ilmu Syari'ah dan Hukum. 2, 1, Januari-Juni 2017: 93-94) merupakan teori yang menjelaskan sosialisasi dan pengaruhnya terhadap perkembangan kepribadian. Teori ini memandang kepribadian individu sebagai respons atas stimulus sosial. Teori ini menekankan bahwa identitas individu bukan hanya merupakan hasil alam bawah sadarnya melainkan karena respons individu atas ekspektasi orang lain. sikap dan perilaku individu tumbuh karena dorongan dari orang sekitarnya seperti yang dikemukakan oleh Bandura : "manusia tidaklah berfungsi apabila sendirian. Sebagai makhluk sosial, manusia mengamati perilaku orang lain dan kesempatan tertentu ketika perilaku tersebut dibalas, diabaikan atau bahkan dihukum. Dengan demikian mereka dapat mengambil manfaat dari konsekuensi yang diamati tersebut dari sebuah pengalaman yang langsung. Menurut Kendra Cherry terdapat tiga konsep inti dalam Social Learning Theory. Konsep yang pertama yaitu orang dapat belajar dari pengamatan (observasi). Yang kedua yaitu keadaan mental batin merupakan bagian esensial dalam proses ini. Dan yang ketiga yaitu pembelajaran belaka belum tentu menghasilkan perubahan pada perilaku.

Keluarga berperan penting dalam tumbuh kembang anak baik secara fisik maupun psikis. Terutama dalam pengelolaan emosi anak, pola asuh orang tua sangat berpengaruh terhadap perkembangan anak, dimana anak akan bisa beradaptasi dengan lingkungan sekitar dan mampu merespons terhadap apa yang dialaminya dan mampu menempatkan emosi apa yang seharusnya dia respon ketika dia mengalami suatu peristiwa di lingkungan keluarga atau bahkan dilingkungan sekitar. Serta bagaimana orang tua dapat memberikan contoh dan pengalaman yang baik terhadap anak mereka supaya mereka dapat meniru yang baik seperti apa yang dia lihat dan rasakan. Untuk itu penulis tertarik untuk membahas "bagaimana peran keluarga dalam pengelolaan emosi anak usia golden age".

\section{METODE}

Penulis menggunakan penelitian kualitatif yaitu dengan pendekatan deskriptif kualitatif yaitu mengumpulkan berbagai informasi dari hasil wawancara dengan sumber yang berkaitan dengan objek penelitian untuk dijadikan bahan referensi dan sumber data (Sugiyono, 2010:10). Pendekatan ini digunakan karena penulis ingin mendeskripsikan tentang peran keluarga dalam mengelola emosi anak usia golden age.

Metode penelitian yang digunakan yaitu dengan pendekatan Social Learning Theory yang berarti tingkah laku manusia terjadi karena adanya interaksi timbal balik yang berkelanjutan antara pengaruh kognitif, behavioral dan lingkungan sekitar. Subjek penelitian adalah orang tua anak usia golden age (1-2 tahun) dan orang tua anak usia (3-4 tahun). Tujuan dari penelitian ini ialah bagaimana peran keluarga khususnya orang tua dalam mengelola emosi anak usia dini (Golden Age)

\section{HASIL DAN PEMBAHASAN}

\section{Definisi Keluarga}

Munandar menjelaskan arti sebuah keluarga (dalam jurnal Wenny Hulukati, Jurnal Musawa, 7, 2, Desember 2015:273-274) merupakan kelompok sosial kecil dari masyarakat yang terbentuk atas dasar pernikahan yang terdiri dari ayah, ibu dan anak. Sedangkan menurut Mudjiono, keluarga merupakan payung kehidupan bagi seorang anak. Dimana keluarga merupakan tempat paling nyaman untuk dia berlindung. Yang mana fungsi dari keluarga itu sendiri ialah sebagai kelangsungan reproduksi, sebagai tempat untuk mempersiapkan anak untuk bertingkah laku yang sesuai dengan nilai dan norma yang berlaku didalam masyarakat dimana ia berada untuk dapat berinteraksi dan bersosialisasi dengan yang lainnya dan yang terakhir sebagai tempat tersedianya kemapanan ekonomi untuk keberlangsungan hidup keluarga. Pada intinya fungsi dari keluarga sendiri yaitu dapat memberikan peranan yang dapat menyiapkan generasi anak yang mampu secara fisik, psikis maupun non fisik. Keluarga yang dimaksud dalam penelitian ini ialah peran keluarga dalam mengelola emosi anak usia dini agar anak dapat menempatkan posisi yang baik dalam emosinya saat melihat suatu peristiwa yang ada disekitarnya.

2. Definisi Golden Age

Periode emas atau golden age (Suyadi, Yogyakarta 2010:23-24) merupakan periode dimana perkembangan otak anak mengalami perkembangan yang pesat dalam sejarah hidupnya. Periode ini berlangsung sejak anak masih dalam kandungan sampai usia dini yaitu 0-6 tahun. Dalam masa bayi dalam kandungan

Dipublikasikan Oleh :

UPT Publikasi dan Pengelolaan Jurnal

Universitas Islam Kalimantan Muhammad Arsyad Al-Banjari Banjarmasin 


\section{Iqoh Maulina $^{1}$ dan Alief Budiyono ${ }^{2}$ \\ Jurnal Mahasiswa BK An-Nur : Berbeda, Bermakna, Mulia \\ Volume 7 Nomor 1 Tahun 2021 \\ Tersedia Online: https://ojs.uniska-bjm.ac.id/index.php/AN-NUR \\ p-ISSN. 2460-9722 | e-ISSN. 2622-8297}

sampai usia 4 tahun merupakan masa yang paling menentukan. Para ahli menyebut usia golden age karena pada masa ini otak anak mengalami pertumbuhan dan perkembangan sangat pesat. Pertumbuhan otak anak pada masa ini mencapai angka $80 \%$ dari otak orang dewasa. Oleh karenanya pertumbuhan kecerdasan otak anak bertumpu pada masa golden age ini.

Dari beberapa definisi diatas dapat disimpulkan usia golden age ini sangat menentukan kualitas seseorang. Pada masa golden age perkembangan potensi yang terdapat dalam diri seorang anak dapat tumbuh dan berkembang sangat cepat dan pesat. Perkembangan tersebut meliputi perkembangan fisik, motorik, intelektual, emosional, bahasa dan sosial (Loeziana Uce, Jurnal Pendidikan Anak, Bunaya. 1, 2, Juli 2015:79 ). Dalam penelitian ini fokus pada peran keluarga atau orang tua dalam pengelolaan emosi anak usia golden age agar anak dapat mengerti emosi apa yang akan dia perlihatkan pada saat terjadi suatu peristiwa yang ada disekitarnya.

3. Perkembangan Usia Golden Age

Golden age sering disebut sebagai masa konsepsi, (Ahmad Yusuf Prasetiawan, Jurnal Pendidikan dan Pembelajaran Dasar. 6, 1, Juni 2019:102) baik sejak masih dalam kandungan sampai umur 4 tahun. Dalam usia ini perkembangan sangat cepat dan pesat yang dapat dipengaruhi dari faktor dalam seperti keluarga atau orang tua dan faktor dari luar yaitu lingkungan sekitar atau masyarakat sekitar. Aktivitas anak yang dinamis memberikan kekuatan, daya dan corak pada sikap dan tingkah laku serta dapat mendorong fase-fase perkembangan dengan implus bawaan yang dapat menghidupkan setiap mekanisme potensi jasmani maupun rohani.

4. Landasan munculnya teori Golden Age

Otak (Hibana S. Rahman, Yogyakarta, 2005:33) merupakan pusat dari kepribadian manusia yang sampai sekarang masih menjadi misteri baik secara hakikah maupun harfiah. Otak manusia terdiri dari otak kanan dan otak kiri, yang mana tugas dari otak kanan yang meliputi irama, fantasi, kreasi, imajinasi, kesadaran ruang, warna dan lain sebagainya. Sedangkan tugas dari otak kiri yaitu logika, matemataika, analisis, urutan dan verbal. Masa pembentukan otak awal sangat peka terhadap stimulus dan kemungkinan sangat berpengaruh pada kehidupan yang selanjutnya. Pada masa ini lah yang sering disebut Golden Age. Dapat dilihat dari perkembangannya, tahap perkembangan otak manusia pada usia dini menempati posisi yang paling vital yaitu mencapai $80 \%$ dari keseluruhan perkembangan kemampuan otak. Bayi lahir telah mencapai perkembangan otak $25 \%$ dari orang dewasa. Untuk mencapai perkembangan otak manusia $50 \%$ dapat dicapai hingga usia 4 tahun, sedangkan untuk $80 \%$ hingga anak usia 8 tahun, selanjutnya proses hingga usia anak 18 tahun. Dengan demikian usia golden age ini terjadi pada saat anak usia 0-8 tahun. Dalam usia itulah penting untuk memberikan rangsangan kecerdasan dengan memperhatikan pola asuh, kesehatan, pendidikan, penyediaan gizi yang itu semua berguna untuk untuk menunjang pertumbuhan dan perkembangan anak. Bukan hanya untuk perkembangan otak saja tetapi juga seluruh aspek perkembangan seperti fisik, psikis, emosi maupun sosial anak. Menurut Goleman, Izard dan Ackerman, Le Doux, secara fisiologis dan psikologis emosi merupakan aspek penting yang digunakan untuk memusatkan perhatian dan kemudian dapat merespons berbagai peristiwa yang terjadi disekitarnya.

5. Aspek perkembangan Golden Age

Untuk mencapai hasil yang optimal dalam perkembangan anak, ada beberapa syarat pokok antara lain mengenali karakter yang dapat berupa aspek kognitif atau intelektual. Terdapat beberapa aspek perkembangan pada masa golden age yaitu kesadaran personal, kesehatan emosional, komunikasi, kognisi, sosialisasi, keterampilan motorik, sosial-emosional, fisikmotorik, bahasa serta pemahaman nilai moral dan agama. Sedangkan aspek yang berkembang antara lain : perhatian, perasaan, ingatan, berpikir, pengamatan, tanggapan, fantasi. Kemampuan yang lahir sebagai konsekuensi perkembangan aspek tersebut seperti fokus dan konsentrasi yang mulai meningkat, fantasi dan imaginasi pada situasi dan kondisi tertentu, kemampuan menghafal tinggi, kemampuan berbahasa yang baik. Selain itu lahir juga inisiatif dan ide dalam menciptakan dan memecahkan permasalahan, yang mana telah ditandai sudah berfungsinya perasaan yang berupa sensibilitas, apresiasi dan reward (Ahmad

Dipublikasikan Oleh :

UPT Publikasi dan Pengelolaan Jurnal

Universitas Islam Kalimantan Muhammad Arsyad Al-Banjari Banjarmasin 
Yusuf Prasetiawan, Jurnal Pendidikan dan Pembelajaran Dasar. 6, 1, Juni 2019:104).

6. Definisi Emosi

Definisi emosi berasal dari bahasa latin yaitu "movere" yang berarti bergerak atau menggerakkan, dari kata tersebut emosi dapat diartikan sebagai dorongan untuk bertindak (Riana Mashar, Jakarta. 2011:16)

Emosi merujuk pada suatu perasaan atau pikiran-pikiran khasnya, suatu keadaan biologis dan psikologis serta serangkaian kecenderungan untuk bertindak. Emosi ini dapat berupa kebahagiaan, ketakutan, cinta, marah, terkejut, jijik dan rasa sedih.

Menurut Hansen dan Zambo (dalam jurnal Wisjnu Martani, Jurnal Psikologi. 39, 1, Juni 2012: 112-113) memberikan contoh fungsi emosi yaitu perasaan takut. Takut sendiri meruapakan salah satu contoh emosi yang digunakan untuk "survival". Pada saat emosi itu muncul maka anak akan sadar terhadap lingkungannya dan menimbulkan sikap hati-hati pada diri anak tersebut. Emosi pada anak usia dini dapat berkembang dari yang sederhana menjadi ke suatu yang lebih kompleks lagi. Salah satu yang berperan penting dalam pengelolaan emosi anak adalah orang tua lalu baru ke lingkungan sekitar.

Menurut Walgito (Riana Mashar, Jakarta. 2011:16-17) mengemukakan tiga teori emosi yaitu :

a. Teori sentral, Gejala kejasmanian merupakan akibat dari emosi yang dialami oleh individu, jadi individu mengalami emosi terlebih dahulu kemudian mengalami perubahan yang terjadi dalam kejasmaniannya. Sebagai contoh misal ada orang menangis karena merasa sedih.

b. Teori periferal, Menurut teori ini justru sebaliknya, gejala kejasmaniannya bukanlah akibat dari emosi yang dialami individu, tetapi emosi yang dialami individu ini merupakan akibat dari gejala-gejala kejasmanian.

c. Teori kepribadian, Emosi ialah suatu aktivitas pribadi, dimana pribadi tidak dapat dipisahkan dalam jasmani dan psikis sebagai dua substansi yang terpisah, maka emosi meliputi pula perubahan-perubahan kejasmanian.
7. Mekanisme emosi

Lewis dan Rosenblum (Riana Mashar, Jakarta. 2011:17-18) mengemukakan proses terjadinya emosi melalui lima tahapan yaitu :

a. Elicitors yaitu adanya dorongan berupa situasi atau peristiwa. Misalnya didekati oleh seekor harimau

b. Receptors yaitu aktivitas dipusat sistem saraf. Setelah indera menerima rangsangan dari luar, dalam hal ini mata melihat mendekatnya seekor harimau, maka mata berfungsi sebagai indra penerima stimulus atau reseptor awal. Setelah mata menerima stimulus, informasi tersebut diteruskan ke otak sebagai pusat sistem saraf.

c. State yaitu perubahan spesifik yang terjadi dalam aspek fisiologis. Dalam kasus ini, contohnya setelah rangsangan mencapai otak maka otak menerjemahkan dan mengolah stimulus ini serta menyebarkan kembali stimulus yang telah diterjemahkan ke berbagai bagian tubuh lain yang terkait sehingga terjadi perubahan fisiologis, seperti jantung berdetak lebih kencang, tekanan darah naik, badan tegang atau bahkan terjadi perubahan pada hormon lainnya.

d. Expression yaitu terjadinya perubahan pada daerah yang dapat diamati, seperti wajah, suara, tubuh atau tindakan yang terdorong oleh perubahan fisiologis. Sebagai contoh otot wajah mengencang, mulut terbuka, suara keras atau berteriak atau bahkan lari kencang menjauh, tubuh tegang.

e. Experience yaitu persepsi dan interpretasi individu pada kondisi emosionalnya. Dengan pengalaman individu dalam menerjemahkan dan merasakan perasaan sebagai rasa takut, stres terkejut dan ngeri.

8. Pola perkembangan emosi

Menurut Desmita (Riana Mashar, Jakarta. 2011:25-26) terdapat empat pola perkembangan emosi anak yaitu :

a. Perkembangan temperamen, temperamen merupakan sebuah perbedaan kualitas dan intensitas respons emosional serta pengaturan diri yang dapat memunculkan perilaku individu sejak lahir, relatif stabil dari waktu ke waktu dan pada semua situasi, yang 
dipengaruhi interaksi antara pembawaan, pengalaman dan kematangan. Konsistensi temperamen ini dibentuk oleh faktor keturunan, pengalaman, kematangan dan terutama pada pola asuh orang tua.

b. Perkembangan kedekatan (attachment), Attachment merupakan ikatan antara dua individu atau bahkan lebih. Attachment menurut Seifrt dan Hoffnung diartikan sebagai hubungan timbal balik antara ibu dan anak, walaupun satu sama lain berbeda dalam memenuhi kebutuhan kedekatan emosional dan fisiknya. Rasa kedekatan ini dibagi menjadi dua bagian yaitu kedekatan yang aman (secure attachment) dan ketertarikan yang tidak aman (insecure attachment).

c. Perkembangan rasa percaya diri, pada dasarnya setiap anak pasti akan mengalami rasa percaya diri dan tidak percaya diri. Rasa percaya diri akan muncul ketika anak merasa nyaman dan percaya pada dirinya sendiri. Sedangkan rasa tidak percaya ini ini muncul ketika anak merasa tidak nyaman dan tidak ada kepercayaan diri terhadap dirinya sendiri.

d. Perkembangan otonomi, perkembangan otonomi atau kemandirian merupakan sebuah tahapan kedua perkembangan psikososial yang berlangsung pada masa bayi dan masa anak baru bisa berjalan.

Perkembangan emosi umum yang terjadi pada awal masa kanak-kanak (Rumini S dan Sundari S, Jakarta. 2004: 48-49) antara lain :

a. Marah, berbagai bentuk ungkapan marah seperti berteriak, menangis, menggertak, menendang, memukul, melompat dan lainlain. penyebab emosi marah biasanya terjadi karena tidak tercapainya keinginan anak, bertengkar dengan teman, berebut mainan dan lain sebagainya.

b. Takut, situasi, kondisi dan lingkungan yang tidak mendukung pada anak. Reaksi dalam mengekspresikan ketakutannya seperti panik pada diri sendiri, menghindar, lari bersembunyi dan menangis.

c. Cemburu, disebabkan karena anak merasa orang tua membagi kasih sayangnya kepada adik, saudara atau orang lain. ungkapan cemburu pada umumnya dilakukan dengan anak melakukan berbagai kegiatan untuk mencuri perhatian orang tua misal menjadi nakal, agresif dan melakukan hal-hal yang belum pernah dilakukan

d. Ingin tahu, rasa ingin tahu anak sangatlah tinggi ketika hal-hal baru disekitarnya belum pernah dia lihat dan rasakan. Reaksi ini biasanya diungkapkan ketika melihat sesuatu yang baru diperhatikan lalu ditirukan

e. Iri hati, dialami beberapa anak yang disebabkan karena menginginkan sesuatu yang dimiliki orang lain yang berupa mainan, barang atau mencari perhatian dan mendapatkan kasih sayang dari orang tua.

f. Gembira , ketika lingkungan menurut dia aman dan nyaman anak akan cenderung merasakan gembira apalagi ketika melakukan aktivitas kegiatan bermainnya. Kegembiraan dapat diungkapkan dengan tersenyum, tertawa, bertepuk tangan, melompat-lompat, memeluk orang tua, teman dan lain sebagainya.

g. Sedih, Anak merasakan sedih ketika dia kehilangan sesuatu yang disenangi atau keinginannya tidak terpenuhi. Ungkapan sedih ini biasanya dengan menangis, merenung, tidak melakukan hal-hal seperti biasanya yang dia lakukan.

h. Kasih sayang, Anak mendapatkan kasih sayang dari orang tua dan orang-orang terdekat dia. Diharapkan dengan anak mendapatkan kasih sayang dari orang tua dan keluarga atau masyarakat sekitar anak dapat belajar mencintai dan menyanyangi mereka seperti apa yang si anak dapatkan.

9. Faktor yang mempengaruhi perkembangan emosi pada anak

Menurut pendapat Hurlock dan Lazarus, (Riana Mashar, Jakarta. 2011: 19-20) perkembangan emosi anak dapat dipengaruhi oleh dua faktor penting yaitu adanya proses kematangan (maturation) dan faktor belajar. Dari kedua faktor ini, Hurlock lebih menekankan pada faktor belajar untuk membantu perkembangan emosi anak, karena dengan belajar anak lebih mudah untuk dikendalikan. Selain faktor belajar, faktor kematangan pun ikut berperan penting dalam perkembangan emosi anak yaitu pada saat anak siap untuk menerima rangsangan dari luar. Menurut Kostelnik, Soderman dan Whiren, masa kanak-kanak memiliki banyak peluang untuk berubah secara signifikan dalam perkembangan anak baik secara psikis maupun fisik dan secara lingkungan. Dalam proses belajar, lingkungan menjadi faktor yang

Dipublikasikan Oleh :

UPT Publikasi dan Pengelolaan Jurnal

Universitas Islam Kalimantan Muhammad Arsyad Al-Banjari Banjarmasin 


\section{Iqoh Maulina $^{1}$ dan Alief Budiyono ${ }^{2}$ \\ Jurnal Mahasiswa BK An-Nur : Berbeda, Bermakna, Mulia \\ Volume 7 Nomor 1 Tahun 2021 \\ Tersedia Online: https://ojs.uniska-bjm.ac.id/index.php/AN-NUR \\ p-ISSN. 2460-9722 | e-ISSN. 2622-8297}

berpengaruh besar terhadap perkembangan emosi anak, yang biasanya mulai dari lingkungan terdekat anak seperti ibu, ayah dan keluarga terdekat lainnya ataupun pengasuh anak. Menurut Thompson dan Lagatutta mengemukakan bahwa perkembangan emosi anak sangat dipengaruhi oleh pengalaman dan hubungan keluarga dalam setiap hari, anak dapat belajar emosi baik dari rangsangan maupun konsekuensinya. Sedangkan Goleman menyatakan bahwa tingkah laku seseorang ditentukan oleh lingkungan sekitar, apa yang dialami dan dipelajari dalam kehidupan sehari-hari yang lebih menentukan tingkah laku dan tanggapan emosi. Jika sejak usia dini dilatih emosi yang tepat maka kecerdasan emosinya akan baik dan meningkat.

\section{PENUTUP}

a. Kesimpulan

Keluarga termasuk anak akan berpikir dan berperilaku sesuai dengan perannya untuk memenuhi kebutuhan emosionalnya. Dalam melaksanakan tugas sesuai dengan perannya dalam keluarga tidaklah mudah, jika tidak tercipta komunikasi yang sehat dan efektif. Untuk memenuhi kebutuhan emosionalnya yang tidak sesuai akan menghasilkan masalah bagi anak dan orang tua. Untuk itu peran orang tua disini sangat lah penting bagi anak, karena anak akan cenderung menirukan emosi apa yang diajarkan oleh orang tua ketika terjadi suatu peristiwa yang menimpanya.

Social learning theory merupakan teori yang menjelaskan sosialisasi dan pengaruhnya terhadap perkembangan kepribadian. Faktor belajar untuk membantu perkembangan emosi anak, karena dengan belajar anak lebih mudah untuk dikendalikan. Selain faktor belajar, faktor kematangan pun ikut berperan penting dalam perkembangan emosi anak yaitu pada saat anak siap untuk menerima rangsangan dari luar. Sikap dan perilaku individu tumbuh karena dorongan dari orang sekitarnya seperti yang dikemukakan oleh Bandura : "manusia tidaklah berfungsi apabila sendirian. Sebagai makhluk sosial, manusia mengamati perilaku orang lain dan kesempatan tertentu ketika perilaku tersebut dibalas, diabaikan atau bahkan dihukum. Dari teori diatas sesuai dengan apa yang didiskusikan penulis bersama narasumber atau orang tua dari si anak. Anak cenderung mengamati sikap dan perilaku orang tuanya atau orang-orang terdekatnya lalu menirukan seperti ketika si ibu menyanyi si anak akan cenderung menirukan dengan emosi yang menunjukkan si anak bahagia. Melihat seperti itu orang tua harus selalu mengajarkan hal-hal baik supaya anak mereka dapat meniru hal-hal yang baik juga dari yang dia lihat. Orang tua harus berperan aktif dalam perkembangan emosional anak supaya anak dapat terus berinteraksi dan berkomunikasi dengan lingkungan sekitar.

b. Saran

Orang tua harus bisa mengendalikan emosi anak agar tidak berlebihan dan sesuai dengan apa yang terjadi. Orang tua juga harus bisa memanfaatkan usia golden age ini lebih baik lagi agar anak dapat tumbuh dan berkembang sesuai dengan apa yang diinginkan oleh orang tua.

\section{REFERENSI}

Ainiyah, Qurrotul. (2017). Social Learning Theory dan Perilaku Agresif Anak dalam Keluarga. Jurnal Ilmu Syari'ah dan Hukum. Vol. 2, No.1, Januari-Juni. Fakultas Syari'ah. IAIN Surakarta.

Hulukati, Wenny. (2015). Peran lingkungan keluarga terhadap perkembangan anak. Jurnal Musawa. Vol. 7, No. 2, Desember.

Jamiah, Yulis. (2012). Keluarga Harmonis dan Implikasinya Terhadap Pembentukan Kepribadian Anak Usia Dini. Jurnal Matematika, PMIPA, FKIP, Universitas Tanjungpura, Pontianak.

Marrtani, Wisjnu. (2012) Metode Stimulasi dan Perkembangan Emosi Anak Usia Dini. Jurnal Psikologi. Vol. 39, No. 1, Juni. Fakultas Psikologi, Universitas Gadjah Mada.

Mashar, Riana. (2011). Emosi Anak Usia Dini dan Strategi Pengembangannya. Jakarta: Kencana Prenadamedia Grup

Prasetiawan, Ahmad Yusuf. (2019). Perkembangan Golden Age dalam Perspektif Pendidikan Islam. Jurnal Pendidikan dan Pembelajaran Dasar. Universitas Jenderal Soedirman Purwokerto. Vol. 6, Nomor 1, Juni.

Rahman, Hibana S. (2005). Konsep Dasar Pendidikan Anak Usia Dini. Yogyakarta: PGTKI Press

Rumini S dan Sundari S. (2004). Perkembangan Anak dan Remaja. Jakarta: Rineka Cipta

Dipublikasikan Oleh :

UPT Publikasi dan Pengelolaan Jurnal

Universitas Islam Kalimantan Muhammad Arsyad Al-Banjari Banjarmasin 
Iqoh Maulina $^{1}$ dan Alief Budiyono ${ }^{2}$ Jurnal Mahasiswa BK An-Nur : Berbeda, Bermakna, Mulia

Volume 7 Nomor 1 Tahun 2021

Tersedia Online: https://ojs.uniska-bjm.ac.id/index.php/AN-NUR

p-ISSN. 2460-9722 | e-ISSN. 2622-8297

Sugiyono, (2010). Metode Penelitian Pendidikan Pendekatan Kuantitatif, Kualitatif dan $R \& D$. Bandung: Alfabeta

Suyadi. (2010). Psikologi Belajar PAUD. Yogyakarta: Pedagogia Cetakan 1

Uce, Loeziana. (2015). The Golden Age: Masa Efektif Merancang Kualitas Anak. Jurnal Pendidikan Anak, Bunaya. Vol. 1, No. 2, Juli.

Dipublikasikan Oleh :

UPT Publikasi dan Pengelolaan Jurnal

Universitas Islam Kalimantan Muhammad Arsyad Al-Banjari Banjarmasin 